\title{
Professional Examinations
}

\section{For Public Health Service Officers}

\author{
By SIDNeY H. NEWMAN, Ph.D.
}

Professional examinations play a significant role in the professional lives of the individuals who take them. Traditionally, they have been of the essay or discussion type. Only recently has the objective type of examination been used in professional examinations. But more and more, objective professional examinations for a variety of purposes are being developed by Federal and State civil service systems, by professional specialty or diplomate boards, by professional licensing boards, and by professional or graduate schools $(1-7)$. The Public Health Service is in the fore of this trend.

The problems of examining candidates for appointment as commissioned officers in the Public Health Service are relevant to all professional examinations. To be considered are the factors of fairness and accuracy, adequacy of construction, and measurement of professional competence and significant intellectual processes.

\section{Officer Selection}

Membership in the commissioned officer corps of the Public Health Service offers a lifetime career to the successful candidate. The Public Health Service offers two types of commissions: Regular and Reserve. Officer grades and salaries correspond to their equivalents in the Army and Navy.

Dr. Newman, a psychologist, is chief of the research branch, Division of Commissioned Officers of the Public Health Service.
The officer selection and evaluation program of the Public Health Service, initiated in the fall of 1947, is among the first to attack, in a broad and systematic manner, the problems of selection and evaluation of medical, scientific, and other professional health personnel. The development of efficient, objective methods for selecting the best qualified officers and for assuring equitable personnel actions within the commissioned corps is the goal of the program.

Professional examinations constitute only a part of the selection and evaluation procedures of the program. Background, personality, interest, and aptitudes are all recognized as factors important to the success of a Public Health Service officer. Selection methods also include interview board and file-evaluation board procedures as well as medical examinations (8).

\section{Why Professional Examinations?}

Professional examinations are designed to measure professional competence and knowledge. The individual undergoing examination is expected to demonstrate his ability to understand and to utilize the principles and knowledge of his profession. In solving examination problems, moreover, he will use the intellectual processes of reasoning, judgment, organization of ideas, integration of specific facts into generalizations, and application of facts and principles.

There is ample evidence that examinations are measuring individual differences among applicants for the commissioned officer corps. The evidence lies in the widely distributed scores 
in the 150 or more different objective professional examinations which have been administered since 1947.

It is apparent that the possession of like professional degrees does not guarantee the exhibition of similar professional abilities, as measured by the tests. Professional competence is a clear-cut requisite for satisfactory performance in the commissioned officer corps. Therefore, it is important to identify all candidates who stand relatively low on the scoring.

\section{Objective Examinations}

The objective type of test is most commonly utilized because of its generally accepted advantages over the discussion or essay kind:

More accurate and more equitable comparisons among candidates are possible because the rapid machine-scoring of the tests is uniform, and bias is eliminated.

By yielding more reliable and more stable results, the test scores are better suited to statistical treatment, making it possible to develop test standards and to compare groups of candidates.

The candidate is required to deal with the subject of the question, thereby revealing his strength or weakness.

It is possible to examine a candidate's professional competence and knowledge more quickly, more intensively, and more extensively.

The five-alternative multiple-choice form is the kind of objective question now used. The question states a problem or situation and presents five answers or solutions, only one of which is considered to be correct. The question is not limited to verbal material-it may contain diagrams, pictures, graphs, symbols, or numbers.

Although it is planned to explore the possibilities of other objective test forms, three main considerations led to the current use of the multiple-choice question. First of all, it lends itself to reliable, uniform, and stable scoring. It can be carefully constructed to measure complex intellectual processes. Also, it has been found easier to demonstrate to subject-matter experts the construction of complex multiple- choice items than the construction of various other forms of items.

Questions which assess rote memory and straight knowledge are used as little as possible.

From four to six 3-hour objective examinations in each professional category are used in selecting officer candidates for the Regular Corps. Objective examinations are also used, partly, for promotions within the Regular Corps to the grades of assistant and senior assistant, which are the equivalents in the Navy, for example, of lieutenant, j. g., and lieutenant. A brief but comprehensive 3-hour test is administered to Reserve Corps applicants in designated categories. Each examination usually contains from 100 to 150 items.

\section{Practical and Essay-Type Examinations}

Two other types of professional examinations are used in the selection and evaluation program. These are the 10-hour practical work examination for dental officer candidates and a specially devised essay examination for scientist officer candidates.

In the practical dental examination, the candidate places an amalgam restoration in a patient's mouth and constructs a gold inlay in a green or ivorine tooth. The candidate is observed while performing the restoration at an examining center by two dental officers who independently rate his work on specially constructed observation-rating schedules. The gold inlays are sent to a central board of three dental officers in Washington who independently grade the cavity preparation and the finished inlays on special rating scales. The third part of the examination is completely objective: the candidate responds to multiplechoice questions by identifying oral pathological conditions which have been depicted on color slides.

Various studies of the observation and rating methods used in the practical dental examination are in progress. The administration and scoring of the practical examination have proved to be satisfactory. It is likely that practical work tests in some other professional categories would also be useful.

In the scientist officer examination, the discussion-type questions on scientific problems 
and research are planned to measure characteristics of originality, judgment, and organization and expression of ideas. Even though this kind of question does have disadvantages, it is worth while to see if the essay question, when carefully constructed by scientist officers, could aid in the measurement of complex intellectual processes.

Rating scales similar to those generally used for evaluating individual performance have been developed for improving the grading of the essay question. Degrees of performance are defined for the graders, and score points are assigned to each question. Three scientist officers independently grade each paper.

The specially devised essay examination for scientist officers will afford an opportunity to study the reliability of this type of approach as well as the relationship between scores obtained by essay and objective methods.

\section{Examination Construction}

The Professional Examination Service staff of the American Public Health Association collaborates with the research branch personnel of the Division of Commissioned Officers of the Public Health Service in constructing objective examinations. In this cooperative endeavor, each organization performs the functions it is best equipped to do. The determination of examination policy, structure, and content is the responsibility of the research branch and other Public Health Service officers. The APHA Professional Examination Service staff aids and advises in the planning.

Procedural steps in constructing professional examinations are outlined:

1. Specialists in the professional fields prepare outlines covering the subject matter relevant to the training and experience requirements for each profession.

2. Experts in the subject profession prepare examination items on specified topics. They are given instructions for constructing multiplechoice questions and descriptions of the intellectual processes which the items should measure.

3. Test construction specialists check the items for format, grammar, and intelligibility.

4. A specialist in the subject field reviews the items for accuracy, content, and adherence to construction outline.

5. Experts in the appropriate professional field review logically grouped items.

6. Specialists revise the items in the light of criticisms from the expert reviewers.

7. Experts select the best of the reviewed items and arrange them in the examination according to subject matter and estimated difficulty.

After administration of each examination, continuous analyses of test scores and test items are used to improve and revise the examinations.

Test-construction procedures give reasonable assurance of the soundness, accuracy, and appropriateness of each item. Up to the present, approximately 1,900 experts in various professional fields have participated in the construction of tests. About 80 percent of these experts are not in the Public Health Service. A minimum of five experts reviews each test item.

\section{Regular Corps Examinations}

Professional examinations have been developed for selection of Regular Corps officers in each of the 10 major professional categories of the commissioned officer corps. Within professional categories, entrance and promotion examinations are given for the grades of junior assistant, assistant, and senior assistant. Professional examinations for different grades may bear the same title but may vary in content or in scoring standards.

The scope and variety of professional examinations which have been prepared for the Regular Corps since 1947 are seen in the list.

New examinations for physical therapist, sanitarian (medical social worker), sanitarian (psychiatric social worker), and scientist (physicist) are in preparation, to be given for the first time in 1952-53.

\section{Effectiveness}

Underlying the use of the professional examination is the theory that measurable differences in professional competence will be related to professional competence exhibited later in the Public Health Service. Testing this theory is 


\section{DENTAL OFFICER}

Oral : Bacteriology, pathology, medicine, and surgery.

General: Anatomy, pathology, and pharmacology.

Operative and prosthetic dentistry, and dental materials.

Periodontia, roentgenology, pedo dontia, and dental public health.

Practical work-performance.

\section{DIETETICS OFFICER}

Junior Assistant and Assistant

Institutional management.

Meal planning and quantity cooking.

Bacteriology and physiology.

Chemistry of food, elementary food chemistry, and chemistry.

Normal nutrition and diet in disease.

\section{Senior Assistant}

Institutional management.

Meal planning and quantity cooking.

Bacteriology and chemistry of food.

Diet in disease, advanced.

Diet and advanced nutrition.

Educational psychology and teaching methods.

\section{MEDICAL OFFICER}

Medical sciences A : Anatomy, physiology, and biochemistry.

Medical sciences B: Pathology and microbiology.

Practice of medicine.

Practice of surgery.

Preventive medicine and public health.

\section{NURSE OFFICER}

Principles and practice of nursing2 parts.

Hospital Nurse Option
Advanced nursing principles and pol-
icies-hospital nursing.
Supervision and teaching princi-
ples-hospital nursing.
Public Health Nurse Option
Principles and policies in public
health nursing.
Supervision and teaching princi-
ples-public health nursing.

\section{PHARMACIST OFFICER}

Practice of pharmacy.

Physiology and pharmacology.

Pharmaceutical chemistries.

Pharmaceutical administration.

Bacteriology and public health.

\section{SANITARIAN AND SCIENTIST OFFICERS}

\section{Bacteriologist}

Teneral bacteriology. Applied bacteriology. Infection and immunity.

Pathogenic bacteria.

Other pathogenic organisms.

Related sciences.

\section{Chemist}

Inorganic chemistry.

Analytical chemistry.

Physical chemistry.

Organic chemistry.

Biochemistry.

Basic sciences.

\section{Entomologist}

Entomology-2 parts.

Scientific method.

General parasitology.

Scientific professional problems and research.

Basic sciences.

\section{Parasitologist}

Parasitology-2 parts.

Scientific method.

General parasitology.

Scientific professional problems and research.

Basic sciences. difficult, primarily because of the necessity for finding a reliable measure or criterion of professional competence as demonstrated on the job. A first approach to this problem has been made.

\section{Criteria of Success}

As a research project, Public Health Service officers at many installations rated each other on 20-point rating scales. These strictly confidential ratings of job proficiency, administrative ability, personality, and value to the Public Health Service were made with the understanding that the results would not be used in any type of personnel action. The ratings became the criteria for developing a new efficiency report and for validating methods of selecting officers. The new efficiency report should be a useful criterion of job performance.

However, such criteria as group ratings and efficiency reports are not actual, direct measures of work performance. Some aspects of job proficiency may be reflected in the group ratings, but other proficiency factors may be omitted.

For example, the practical work examination for dental officer candidates could more directly measure competence in clinical dentistry than could group ratings. This is not to disparage the importance of such ratings as useful criteria, particularly where colleagues might 


\section{Protozoologist}

Protozoology-2 parts.

Scientific method.

General parasitology.

Scientific professional problems and research.

Basic sciences.

\section{SANITARIAN OFFICER}

\section{Health Educator}

Methods and materials of health education.

Public health science and practices.

Principles and administration of health education.

Background information.

\section{Mammalogist}

General biology-2 parts. Mammalogy -2 parts.

\section{Milk and Food Specialist}

Milk and food sanitation-2 parts. General sanitation.

Public health background, methods, and procedures.

\section{Nutritionist}

Nutrition. in health and disease. General and food chemistry. Group feeding. General sanitation and hygiene. Public health methods.

\section{Ornithologist}

General biology-2 parts.

Ornithology -2 parts.

\section{SANITARY ENGINEER OFFICER}

\section{Junior Assistant}

Mechanics, thermodynamics, and electricity.

Hydraulics, strength of materials, elementary engineering structures, and surveying.

Mathematics.

Physics and chemistry.

General background and public health methods.

\section{Assistant and Senior Assistant}

Water.

Air and industrial hygiene.

Sewage, stream pollution, and refuse. Insect and rodent control.

Milk and food.

Public health administration.

\section{SCIENTIST OFFICER}

\section{Aquatic Biologist}

General biology-2 parts. Aquatic biology -2 parts.

\section{Biochemist}

Biochemistry-2 parts.

Inorganic and analytical chemistry. Organic and physical chemistry. Basic sciences.

\section{Physiologist}

Muscular, neutral, and sensory systems.

Respiratory and circulatory systems. Nutritive and excretory processes.

Endocrinology, general physiology, and scientific method.

Research.

Basic sciences.

\section{Prychologist}

Clinical psychology-2 parts.

Developmental and social psychology.

Evaluation, measurement, and psychological statistics.

Theoretical, experimental, and physiological psychology.

Related sciences.

\section{VETERINARY MEDICAL OFFICER}

Bacteriology, pathology, and parasitology.

Infectious diseases and epidemiology.

Medicine and surgery.

Public health.

Anatomy, physiology, and biochemistry.

Therapeutics, materia medica, and public health. readily observe factors of job competence during daily contacts.

It is hoped that future research will develop reliable and direct measures of actual work performance in the various professional categories. They could serve as validation criteria for professional examinations, group ratings, and efficiency reports.

\section{Intellectual Measurements}

Corollary to the theory that professional examinations do measure professional competence is the hypothesis that they also are measuring such complex intellectual processes as interpreting, judging, reasoning, and integrating. To test the hypothesis, it is appropri- ate to ask, "What intellectual processes are most closely related to successful performance in the Public Health Service?"

Since multiple-choice items are constructed to measure complex intellectual processes, and are accepted by testing experts as doing so, they furnish a good starting point in seeking answers to the above question. Suitable analytical studies of the relationships between the items might reveal interrelated groups of items, and might yield hypotheses or data on the factors measured by each group. The relationship of each group to criteria of performance in the Public Health Service could then be studied. Those item groups yielding scores most closely related to performance could serve as models for similar items or questions. In addition, 
forms of objective test items other than multiple-choice questions could be similarly investigated.

\section{More Research Needed}

Because there is surprisingly little published research about professional examinations, the experience of the officer selection and evaluation program and of the APHA Professional Examination Service will benefit organizations that use, or plan to use, professional examinations. It is evident that careful planning and research are needed to develop professional tests which are adequate, suitable, and appropriate to the measurement that is required and which actually measure professional competence and knowledge with the utmost scientific objectivity.

\section{ACKNOWLEDGMENTS}

Appreciation is expressed for the aid and support of the following officers in the initiation and development of the officer selection and evaluation program: Deputy Surgeon General W. Palmer Dearing, formerly chief, Division of Commissioned Officers (1947-48); Medical Director Eugene A. Gillis, formerly chief, Division of Commissioned Officers (1948-52); Medical Di- rector Robert H. Felix, director, National Institute of Mental Health.

\section{REFERENCES}

(1) Adkins, Dorothy C.: Construction and analysis of achievement tests. Washington, D. C., U. S. Government Printing Office, 1947.

(2) Bierman, Howard R., and McClelland, James N.: An achievement examination in the subject of cancer for medical school students. Pub. Health Rep. 66: 769-778 (1951).

(3) Deming, Dorothy, Long, Lillian D., and La\%o, Elizabeth $\mathbf{K}$. : Progress in merit system unit examinations. Pub. Health Nursing 39: 73-79 (1947).

(4) Deming, Dorothy, Lazo, Elizabeth K., and Long, Lillian D. : An analysis of a public health nursing test. Pub. Health Nursing 42: 9-16 (1950).

(5) Hurd, Archer W. : Evaluating student success in medic·al education. Richmond, Va., Bureau of Educational Research and Service, Medical College of Virginia, 1951.

(6) Long, Lillian D.: The principles and purpose of objective testing. Federation Bull. 37: 295-306 (1951).

(7) Watson, Cecil J.: Some activities and impacts of the American Board of Internal Medicine. J. A. M. A. 138: 257-260 (1948).

(8) Newman, Sidney H.: The officer selection and evaluation program of the U. S. Public Health Service. Am. J. Pub. Health 41: 1395-1402 (1951).

\section{Shaw Heads Division of Hospitals}

The appointment of Dr. James R. Shaw as chief of the Division of Hospitals, Bureau of Medical Services, Public Health Service, was announced in July.

Formerly medical officer in charge of the Public Health Service Hospital, Detroit, Mich., Dr. Shaw succeeds Dr. G. Halsey Hunt, who was recently named associate chief, Bureau of Medical Services.

In 1936, after receiving his medical degree at the University of Michigan Medical School, Dr. Shaw joined the Public Health Service as medical intern, assigned to its hospital at New Orleans, La. In addition to a fellowship in internal medicine at the Mayo Clinic, Dr. Shaw took postgraduate work in hospital administration at Stanford University, San Francisco, and the University of California. Before coming to the Public Health Service Hospital in Detroit, Dr. Shaw's Public Health Service career included assignment in the internal medicine departments of several of its hospitals and out-patient clinics, a tour of duty as district Coast Guard medical officer, Long Beach, Calif., and medical officer in charge of the Public Health Service clinics at Los Angeles and San Pedro, Calif. 